Бажнанова Мария Олеговна

студентка

Научный руководитель

Павлович Татьяна Вячеславовна канд. техн. наук, преподаватель

ФГОБУ ВО «Финансовый университет при Правительстве Российской Федерации»

г. Москва

DOI $10.21661 / r-551548$

\title{
OVERVIEW OF ERP TECHNOLOGIES DEVELOPMENT IN RECENT YEARS
}

Abstract: the article reviews some trends in developing ERP technologies for the last several years. It includes definition of Enterprise resource planning (ERP), a small history of ERP and primary trends in the field. Moreover, this article provides a brief understanding of each of the specified ERP technologies and their benefits. In this article Mobile ERP, Cloud ERP, Social ERP and Two-tier ERP are demonstrated.

Keywords: information systems, Enterprise resource planning (ERP), software, trends.

Аннотация: в статье рассматриваются тенденции развития ЕRP-технологий за последние несколько лет. В статье также представлено определение системы планирования ресурсов предприятия, краткую историю ее развития и основные тенденции и перспективы их развития. Кроме того, в статье дается краткое описание каждой из указанных ЕRP-технологий и их преимущуеств. Демонстрируются мобильные ERP-системы, облачные ERP-системы, социальные ERP-системы и двухуровневые ERP-системы.

Ключевые слова: информационные системы, система планирования ресурсов предприятия, программное обеспечение, тенденции развития. 


\section{Introduction}

Nowadays there are many vendors of ERP systems and market of such software is very spread out all over the world. According to Gartner the worldwide leaders in the ERP field for 2018 are SAP, Oracle, Workday, Sage, Infor. Before we start talking about tendencies in developing ERP technologies let us find out what that systems are meant to be.

Enterprise resource planning technology or ERP is well known as a type of software, which is used to manage day-to-day business activities by organizations and enterprises. These activities include accounting, procurement, project management, risk management and compliance, and even supply chain operations. Enterprise performance management (that refers to plan, budget, predict, and report on an organization's financial results) also gets in with a complete ERP suit.

ERP is slow to change. In fact, there are four main both new and continuing trends which shifting the area of ERP and impact on the growth of enterprise ERP software:

1. Mobile ERP.

2. Cloud ERP.

3. Social ERP.

4. Two-tier ERP.

\section{The history of ERP}

By 1990, the name ERP (Enterprise resource planning) appeared, but what happened before such a technology was created. The history of ERP takes its' roots more than 100 years ago. Engineer Ford Whitman Harris developed the economic order quantity (EOQ) mode in 1913. It was a paper-based manufacturing system for production scheduling. In 1964 Toolmaker Black and Decker created a solution which combine EOQ concepts with a mainframe computer and became known as material requirements planning (MRP) solution.

It remained the manufacturing standard when in 1983 MRP was improved and became manufacturing resource planning (MRP II). MRP II includes «modules» as a key software architectural component. It integrated such core manufacturing components as purchasing, bills of materials, scheduling, and contract management. It was 
the first time when different manufacturing tasks were integrated into a common system.

Within the evolution of computer technology through the 1970s and 1980s the MRP II concepts were developed to manage other business activities like incorporating finance, customer relationship management, and human resources data. Due to such development and changes technology analysts made up a name for such category of business management software - enterprise resource planning or ERP.

\section{Mobile ERP}

Mobile ERP solution is designed special for smartphones or tablets running on platforms such as iOS and Android. An access to mobile platform can be got through the internet using either a dedicated mobile app or a standard mobile browser, for instance, Safari, Google etc.

Mobile ERP system help users create access and share business data in real time and only you need is your mobile device and access the internet. A huge advantage of such solution is this level of access without a costly investment or the need to make any significant changes to an infrastructure.

Some venders of mobile ERP systems are below:

1. SAP Business One.

2. Oracle JD Edwards EnterpriseOne.

3. Microsoft Dynamics AX.

4. Acumatica.

5. NetSuite.

6. IQMS EnterpriseIQ ERP.

7. Sage X3.

8. SYSPRO.

\section{Cloud ERP}

Cloud ERP is Software as a Service (SaaS) which allows users to access ERP software over the Internet. Offering tools and software can be performed and managed in a cloud. That's why technical difference between Cloud ERP and on-premises ERP 
is physical location of the software. With Cloud ERP, users have an opportunity to access their business-critical applications at any time from any location.

The main advantage of Cloud ERP are much lower upfront costs which makes that software particularly valuable to small and medium-size businesses. There is no need to pay much for hardware and software. Furthermore, within the right provider an organization can rapidly change and scale their business productivity software due to their business grows. Let's list more benefits in costs which Cloud ERP provide to businesses:

- reduces upfront costs for IT support services;

- avoids paying upfront for software licenses in favor of a monthly fee;

- reduces the payment for maintaining and supporting those applications because in fact the cloud vendor manages the updates and upgrades;

- companies pay only for computing resources they need;

- as monthly rate is fixed companies have an opportunity to use their cash on other business initiatives.

Other advantages which provides Cloud ERP their users:

- fast star, because installation of hardware and software on servers or user devices is not required;

- the ability to manage of cloud service;

- the opportunity to back up data and then recovery them;

- as the data is stored in a cloud, attacks on the company's server are ineffective;

- access to the system from anywhere gives companies an option for easy geographically expansion.

\section{Social ERP}

There is no secret that social media brings a great revision of how we communicate in business. Social tools become more effective in the workplace when they tied into your ERP solution. There Social ERP comes. Social ERP applications share the functionality of online social networking tools. The interface, which act like, for instance, a website, is fully secured and maintained with your ERP solution also provide quick and handy access for its' users. 
Fundamental advantages of such solution are abilities to assist collaboration and communication in the enterprise, easily track conversations, projects and processes, improve business processes, write documents about business processes in order to support lean initiatives, boost customer involvement, create and manage your knowledge base. Thanks to such benefits for business Social ERP become more and more significant component of the ERP landscape.

\section{Two-tier ERP}

Two-tire ERP is a technology strategy that uses tier 1 ERP and tier 2 ERP together. Moreover, tier $1 \mathrm{ERP}$ as a rule is used for financials and other core common processes, while tier 2 ERP is established for divisions and smaller locations of the organization to address specific needs. The key benefit of Two-tier ERP is that it allows organizations to optimize processes of regional back office at a site which manages under a separated from the main company business model.

Tire 1 ERP is created for huge enterprises to manage the complexity such companies require. That is why these systems are very complex to configure and expensive to implement. The well-known venders of tier 1 ERP are SAP, Oracle, Microsoft Dynamics and Infor.

Tire 2 ERP is less complex and costly than tier 1 . There is tire 3 ERP which is much simpler and less costly to implement. Speaking about tier 2 ERP it should be mentioned Epicor, NetSuite, Plex, Sage and Syspro.

Do not forget that the main concern for companies which deploy two tiers of ERP is mastering data management. That is why the consistency is very important and required at the second tier. It helps to ensure the corporate first-tier ERP can get a single source of information for different business operations.

\section{Список литературы}

1. TAdviser - портал выбора технологий и поставщиков [Электронный ресурс]. - Режим доступа: https://www.tadviser.ru

2. Oracle - Integrated Cloud Applications and Platform Services. URL: https://www.oracle.com 
3. Webopedia: Online Tech Dictionary for IT Professionals. URL: https://www.webopedia.com

4. SearchERP - TechTarget. URL: https://searcherp.techtarget.com

5. Business Software Reviews from Software Advice. URL: https://www.softwareadvice.com

6. Acumatica ERP system - Accelerate Your Business. URL: https://www.acumatica.com

7. Strategic Information Group. URL: https://www.strategic.com 